\title{
A Conceptual Socio-Hydrogeological Model Applied to Sustainable Water Management. Case Study of the Valdivia River Basin, Southwestern Ecuador
}

\author{
Paúl Carrión-Mero ${ }^{1,2}$, Fernando Morante-Carballo ${ }^{1,3,4}$, Valery Vargas-Ormaza ${ }^{5}$, Boris Apolo-Masache ${ }^{1,2^{*}}$, María Jaya- \\ Montalvo ${ }^{1,2}$ \\ ${ }^{1}$ Centro de Investigación y Proyectos Aplicados a las Ciencias de la Tierra (CIPAT), ESPOL Polytechnic University, \\ Guayaquil 09-01-5863, Ecuador \\ ${ }^{2}$ Facultad de Ingeniería en Ciencias de la Tierra (FICT), ESPOL Polytechnic University, Guayaquil 09-01-5863, Ecuador \\ ${ }^{3}$ Facultad de Ciencias Naturales y Matemáticas (FCNM), ESPOL Polytechnic University, Guayaquil 09-01-5863, Ecuador \\ ${ }^{4}$ Geo-Recursos y Aplicaciones GIGA, ESPOL Polytechnic University, Guayaquil 09-01-5863, Ecuador \\ ${ }^{5}$ Junta Administradora de Agua Potable Regional de Manglaralto (JAAPMAN), Manglaralto 241754, Ecuador
}

Corresponding Author Email: bhapolo@espol.edu.ec

https://doi.org/10.18280/ijsdp.160708

Received: 13 September 2021

Accepted: 10 October 2021

Keywords:

aquifer, socio-hydrology, sociohydrogeology, ecological, social

\begin{abstract}
The scientific community has a growing interest in understanding the interaction of the humanwater system in water resource models. In Santa Elena (Ecuador), Valdivia, San Pedro, Sinchal, Barcelona and Carrizal communities are located in a semi-arid area, making the water supply a critical problem for local communities. In addition to the climatic conditions of the sector, the main problem is the weak participation in the integral management of the groundwater resource by the stakeholders involved. Specifically, there is evidence of a lack of ancestral-technical knowledge in management strategies and the fact that the demand for water for agriculture, tourism, and their basic needs exceed the sustainable supply capacity. The present study assesses the natural and anthropic conditions of the middle and lower basin of the Valdivia river through a socio-hydrogeological conceptual model of the river-aquifer system to develop productive activities in an environment of sustainability. The study methodology consists of four phases: i) river basin data analysis, ii) hydrogeological studies, iii) application of the Participatory Action Research (PAR) and Strengths-WeaknessesOpportunities-Threats (SWOT) analysis, and iv) conceptual model of the river-aquifer system. The results show that the socio-hydrogeological model of the Valdivia River basin has four systems: hydrogeological, ecological, economic, and social. In addition, the research detected problems present in the systems, such as droughts due to the influence of natural phenomena, aquifer overexploitation, lack of aquifer sustainability techniques, weak management and control of water resources, contamination of water sources and a lack of support from government agencies. The systems identified allow JAAPR-Valdivia to manage strategies to solve the problems detected in search of the sustainability of water resources.
\end{abstract}

\section{INTRODUCTION}

Freshwater represents only a tiny fraction of the water available on Earth (around 1.8\%) [1, 2], most of which containing in groundwater [2]. However, the constant increase in the demand for freshwater in recent decades has made the severe problem of the shortage of freshwater that our planet presents. The scarcity of vital resources is becoming a threat to the sustainable development of human society [3].

Freshwater is an essential element that underpins almost all the Sustainable Development Goals (SDG), which require access to adequate and safe resources for consumption and sanitation (SDG 6) such as irrigation, energy production and other industrial activities. Furthermore, it contributes to achieving other development goals, including, for example, the elimination of poverty (SDG 1) and hunger (SDG 2), the reduction of inequalities (SDG 10), and good health and wellbeing (SDG 3) [4]. Unfortunately, in recent decades, several countries experience scarcity of water, food and energy resources $[5,6]$ due to anthropogenic climate change and direct human influences such as population increase or migration, economic development, urbanisation and land-use change. Therefore, producing enough food with limited water and energy resources challenges humanity $[7,8]$.

Faced with the new era of the Anthropocene, man can no longer be considered an external driver in hydrological systems but a central part of it, whose system becomes a coupled human-water system [9]. Socio-hydrology is a discrete subfield of the coupled human-water system study [10]. Socio-hydrology is a new scientific discipline [11] that considers people as an endogenous part of the water cycle, interacting with the system in multiple ways, including the consumption of water for food, energy and the supply of drinking water, through pollution of freshwater resources, and policies, markets, and technology [12]. The objectives of socio-hydrology focus on developing the following areas: a) historical socio-hydrology (knowing and studying the past); b) comparative socio-hydrology (compare and examine the 
different water-social systems); and c) socio-hydrological process (understanding the existing hydrological-social systems to be able to estimate possible future trajectories) [12, 13].

In a complementary way, trying to close the gap between science and society, a new approach called "sociohydrogeology" is proposed [14]. Sociohydrogeology is a subdiscipline of socio-hydrology. It aims to study the mutual relationships between people and groundwater, emphasising the social dimension in hydrogeological research $[14,15]$.

The six critical aspects of socio-hydrogeology are: a) evaluation of the impact of human activities on groundwater resources, b) evaluating the socio-economic impact of groundwater resources on human life and well-being, c) analysis of involved, their relationships and conflicts in a specific groundwater problem, d) promote hydrogeological research, e) bridge the gap between science and practice, and fundamentally f) demystify science and scientists [14].

The new discipline "socio-hydrogeology" appeared in 2015 [14], with its bottom-up approach "Bir Al-Nas" on sustainable groundwater management. The "Bir Al-Nas" (meaning "the peoples well") base on hydrogeochemical and social research. The first includes a) water quality and quantity assessment, b) recharge rate assessment, c) sustainable yield definition, and d) modelling. While social research carries out a) stakeholder analysis, b) public engagement assessment, and c) socioeconomic assessment. The "Bir Al-Nas" approach applies in other studies, such as the Grombalia Basin (Tunisia) [16], in identifying the sources of groundwater contamination.

Other socio-hydrogeological approach methods are the case study of evaluation of social and economic development based on the availability of water resources associated with hydrogeomorphological characteristics (Argentina) [17], the identification of sources of salinization and contamination using isotopes of nitrate and boron for the implementation of mitigation measures (Morocco) [18]. In addition, the multidisciplinary study combines hydrogeology, biogeochemistry and socio-hydrogeology [19] by calculating the mass balance of nutrients, evaluation of groundwater contamination, hydrological responses and processes, and identification of stakeholders using the Net-Map tool (Italy).

Socio-hydrogeological studies highlight the link between water and society as a factor of great importance that hydrogeologists must address, and in this way, know the problems present in the water resource and the criticalities on the part of the community. Furthermore, this link will allow obtaining viable and favourable results for users, ensuring strategies that its inhabitants will be able to cope with for its correct use $[16,20]$, demonstrating the importance of socialization with the population in any research work.

Santa Elena is a province located in the southwest of Ecuador, a semi-arid coastal region [21]. The coastal region of Ecuador can divide into wet and dry areas due to the influence of the climatic patterns of the Andes Mountains [22]. Furthermore, the climate is affected by two physicaloceanographic agents: a) the Humboldt Current, with temperatures of $20^{\circ} \mathrm{C}$ and even lower, and b) the El Niño phenomenon, which allows an average temperature of $36^{\circ} \mathrm{C}$ to reaching during the dry season [23]. Therefore, the province of Santa Elena has a primary type of climate defined as drysemi-humid [22]. This province has communities seriously affected by the lack of water, such as the neighbouring communities south of the Valdivia River. The water board called "Junta Administradora de Agua Potable Regional de
Valdivia (JAAPR-Valdivia)" is a community organisation responsible for managing and supplying water, specifically for the communes Sinchal, Barcelona, Valdivia, San Pedro and Carrizal.

Even though rural communities have a developed social structure, the participation of the social system in groundwater management is limited by the lack of basic knowledge of hydrogeology and communication between farmers and the members of the water board to provide solutions to the scarcity of water resources in the region and its sustainability. In this context, to solve the problem of scarcity of water resources. It is essential to integrate the community (social system) with the processes of water sustainability (hydrological system), plus the care and preservation of the environment (ecological system) and greater control of the amount of water consumption by the agricultural sector (economic system). For this reason, the following question arises: How could the application of a participatory socio-hydrogeological conceptual model in the communities surrounding the Valdivia river allow the sustainable use of water and promote agricultural and tourism development in rural communities? The present study evaluates the natural and anthropic conditions of the middle and lower basins of the Valdivia river through a socio-hydrogeological conceptual model of the river-aquifer system to develop productive activities in an environment of sustainability.

\section{METHODOLOGY}

The study methodology consists of four phases, as shown in Figure 1: i) river basin data analysis, ii) hydrogeological studies, iii) application of the Participatory Action Research (PAR) and Strength-Weaknesses-Opportunities-Threats (SWOT) analysis methodology, and iv) conceptual model of the river-aquifer system.

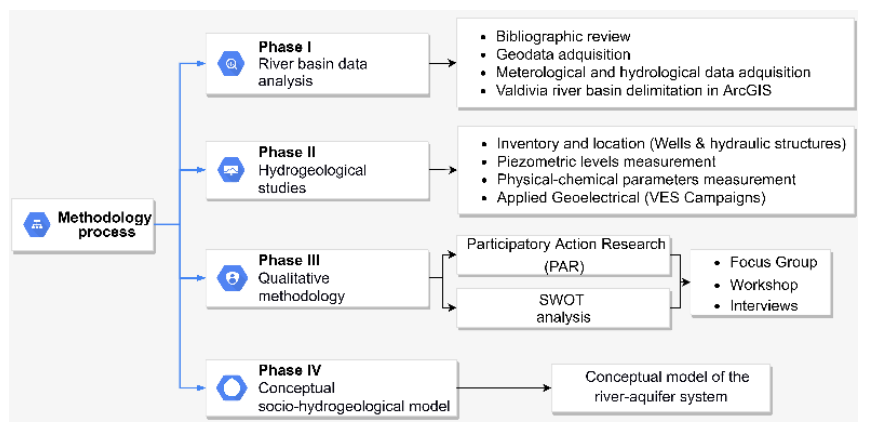

Figure 1. Methodology diagram applied to carry out the research

\subsection{Phase I: River basin data analysis}

Phase I comprises two stages: a bibliographic review and processing previous technical studies, scientific publications, and research projects carried out in the study area. In addition, thematic cartography such as Digital Elevation Model (DEM) [24], aerial images, geology and hydrogeology base maps were compiled and taken from the cover web page of the National Information System of Ecuador (SNI, acronym in Spanish) [25]. Furthermore, Valdivia River basin meteorological data was from the 'El Suspiro' meteorological station (code: M0245). This data includes daily rainfall and temperatures of the National Institute of Meteorology and 
Hydrology [26].

The second stage involved the delimitation of the watershed using the Santa Elena DEM (12.5x12.5 m grid resolution) and subsequent processing in GIS using the Hydrology from the Spatial Analyst toolbox of ESRI ArcMap software version 10.5 .

\subsection{Phase II: Hydrogeological studies}

The second phase consisted of conducting a series of hydrogeological studies in the Valdivia river basin, using field visits, including: a) Inventory and geolocation (water wells and hydraulic structures), b) Piezometric levels and physicalchemical parameters measurement and c) Applied Geoelectrical, which are detailed as follows.

2.2.1 Inventory and geolocation (water wells and hydraulic structures)

The inventory and geographic location (geolocation) of water wells and hydraulic structures (dams, dykes or "tapes" (ancestral hydraulic structure)) is carried out through field trips carrying out with the personnel of the water boards of the communes of the middle and lower Valdivia river basin, using differential GNSS geodetic equipment to understand how the water distribution-extraction system works.

The registry of water wells allows one to know the current state of each one and the type of operation and use. This information will include a geographical map joining with hydraulic structures surrounding each well.

\subsubsection{Piezometric levels and physical-chemical parameters} measurement

Once the water wells and hydraulic structure are inventoried, groundwater levels are measuring with the help of a water level meter. This measurement is when the well pumps are off. The groundwater level data collected will be the base indicators for understanding the aquifer's state and its relationship with the basin environment.

Additionally, the physical-chemical parameters of the water wells were measured in situ using portable WTW 3430 series multiparametric equipment. To obtain these measures, the water extract from the well before turning off the pump, allowing the water trapped in the pipe to flow for a few seconds to take a sample as pure as possible.

The parameters analysed were $\mathrm{pH}$, conductivity $(\mu \mathrm{S} / \mathrm{cm})$, temperature $\left({ }^{\circ} \mathrm{C}\right)$, resistivity $(\Omega \mathrm{m})$, total dissolved solids (TDS) $(\mathrm{mg} / \mathrm{L})$ and salinity of the wells $(\%)$.

\subsubsection{Applied Geoelectrical (VES Campaigns)}

The Vertical Electrical Sounding (VES) technique, used in several groundwater resource exploration studies [27-32]. Seventeen VES campaigns were carried out with $\mathrm{AB} / 2$ of 215 $\mathrm{m}$ and $\mathrm{MN} / 2$ of $20 \mathrm{~m}$, from the northeast to the southwest of the basin, focusing on the Valdivia River. The Terrameter System 1000 equipment used for resistivity data collection sends direct current in short time intervals ranging from 0.5 to 0.4 seconds in duration from the external electrodes (AB). It collects the subsurface information through the internal electrodes (MN). The Schlumberger electrode configuration was applying for the VES locations.

Subsequently, resistivity data were taken in the field interpreting in IPI2win software version 3.0.1 [33], and in this way, know the different layers or strata of rocks that make up the subsoil of the points of interest.

\subsection{Phase III: Qualitative methodology}

In this phase, qualitative methodologies were applying in the communes that make up the JAAPR-Valdivia (Sinchal, Barcelona, Valdivia, San Pedro and Carrizal), using conventional qualitative research techniques such as interviews, workshops and focus groups. These tools made it possible to obtain an overall understanding of the economic, cultural, social, and environmental situation of Valdivia. The method used was Participatory Action Research (PAR), is a cyclical process that allows researchers and community members to work together to define a problem, take action on the issue, and evaluate the effectiveness of the action [34-36]. The process is summarising in Figure 2. Finally, in this phase, a Strengths, Weaknesses, Opportunities and Threats (SWOT) analysis [37] was developed through a participatory workshop with the leading representatives of the communes, where a brainstorming session was held to analyse the general problems of the environment and generate strategies to address the specific issues or challenges identified.

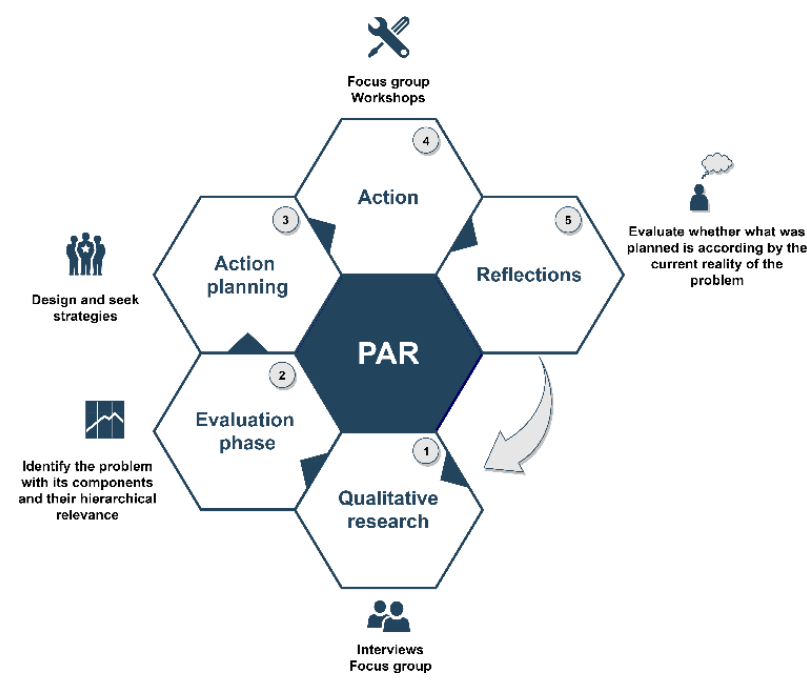

Figure 2. Participatory action research (PAR) method

\subsection{Phase IV: Conceptual socio-hydrogeological model}

In this phase, to obtain the conceptual model of the riveraquifer system of the study basin, it was built based on the evaluation of information from previous phases, geology, hydrology, geophysics (VES campaigns), hydrogeology and socio-economic data. These parameters were crucial to understand and represent a close-to-reality simulation of the current state of both the river and the aquifer. The model began with identifying the variables that make up the basin system, which is the hydrogeological, ecological, economic and social systems. Once the variables have been identifying, the central deficits or problems are establishing to propose appropriate strategies to mitigate them.

\section{RESULTS}

\subsection{Characteristics of the Valdivia river basin}

The Valdivia river basin is classifying into three sub-basins (Figure 3), which allow observing a dissection of the entire study area and delimit optimal areas for the generation of various geoelectric and data collection work to reach the 
proposed objective. These sub-basins are dividing into: i) the upper basin that covers $72.90 \mathrm{~km}^{2}$, while ii) the middle basin is $57.46 \mathrm{~km}^{2}$ and iii) the lower basin with an area of approximately $34.16 \mathrm{~km}^{2}$. In addition, there is a population of 6,552 inhabitants living in the middle and lower basin of the Valdivia River.

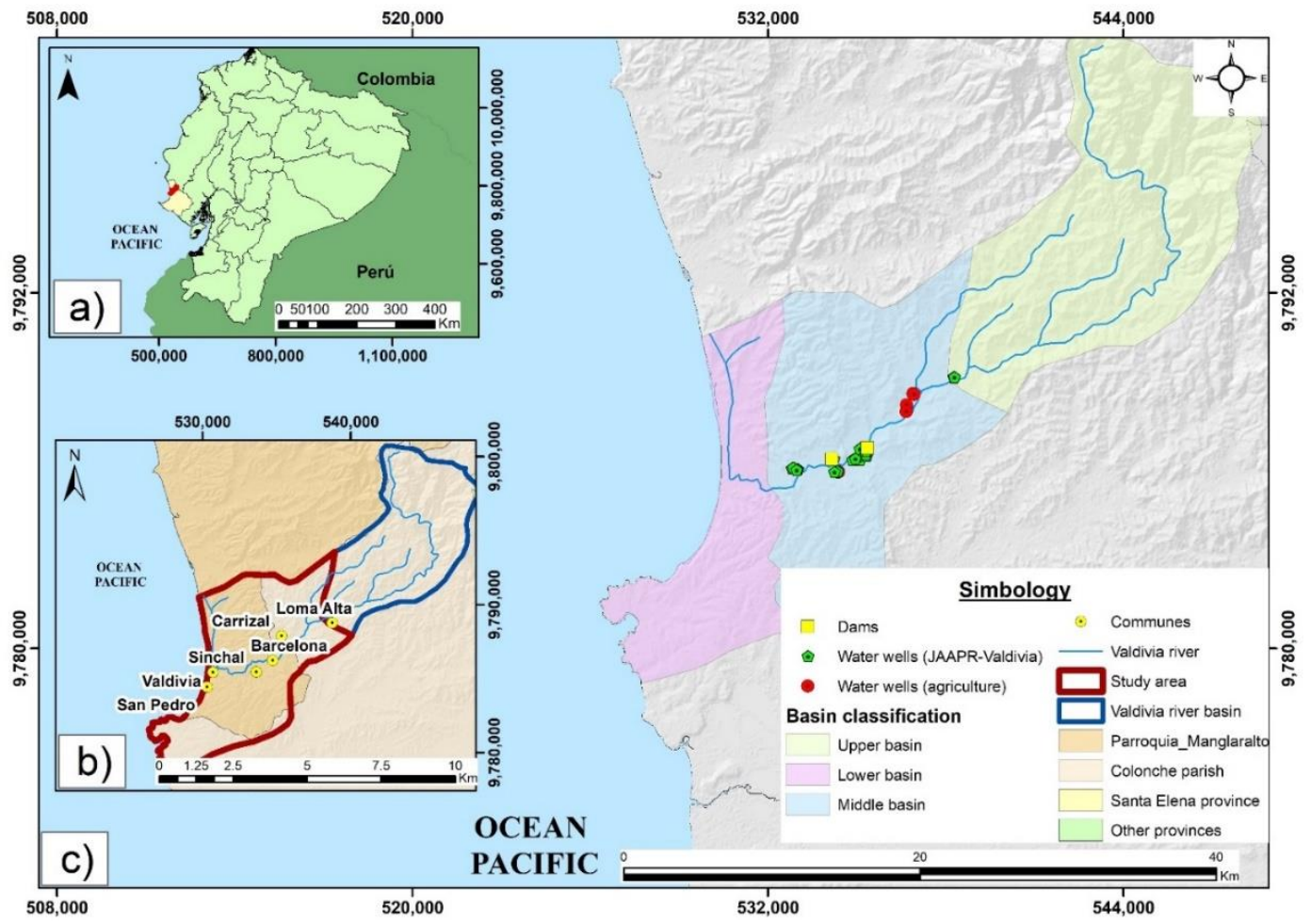

Figure 3. a) Location map; b) Map of the study area; c) Classification of the Valdivia river basin

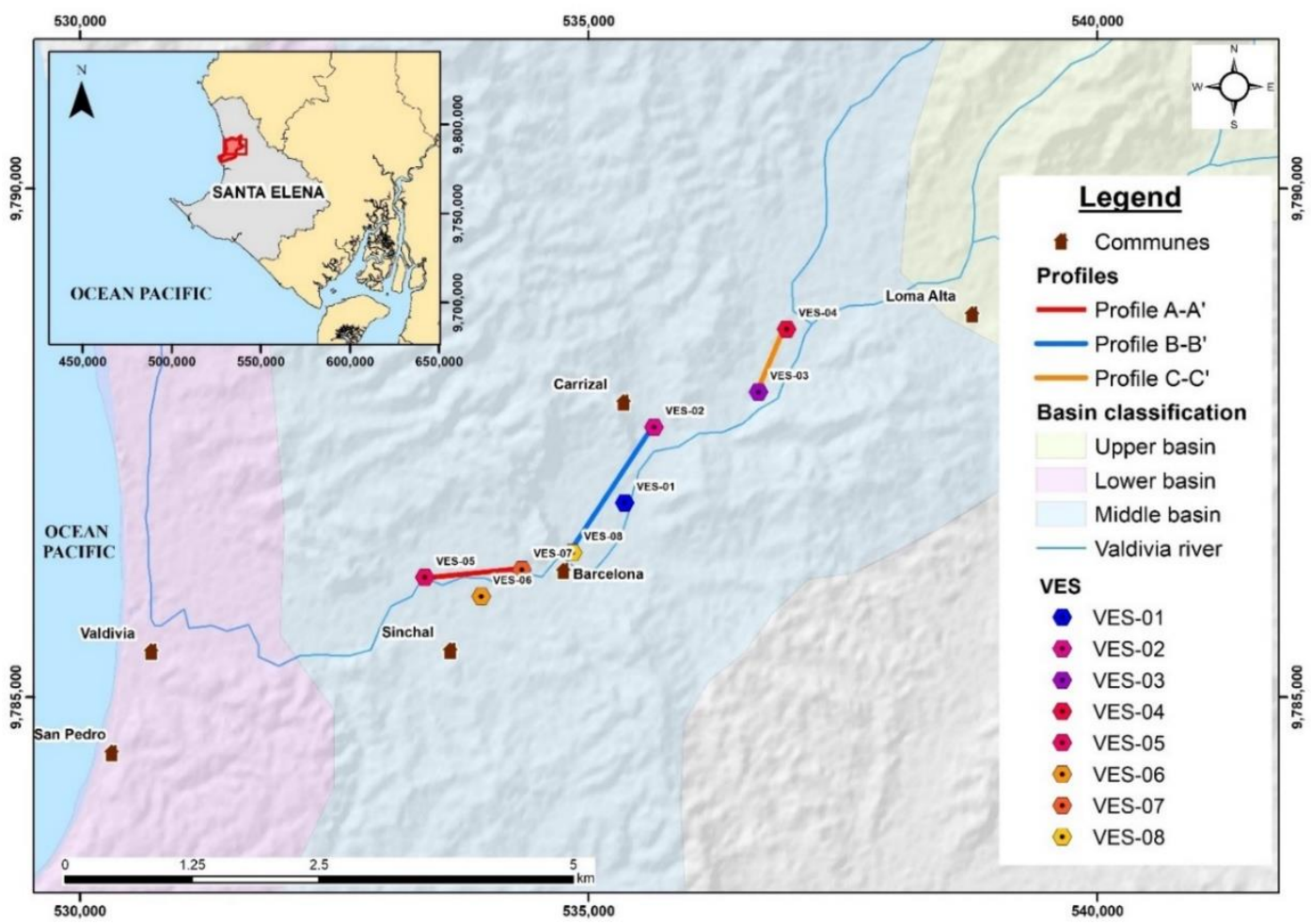

Figure 4. Location of VES and profiles in the middle Valdivia river basin

\subsection{Geoelectric sections}

Based on the basin classification, strategic sections of the middle basin are establishing for the realisation of 17 VES and three profiles from these VES (Figure 4).

The $12 \%$ of the basin comprises alluvial deposits, characterised by fluvial-detrital sediments, gravels, and boulders in a sandy matrix, favouring groundwater accumulation and the subsequent formation of potential aquifers. The $46 \%$ of the basin comprises the Tosagua formation (in the Zapotal member), characterised by sandstones, shales, and conglomerates, with high to medium 
permeability and good porosity. Finally, 23\% of the territory is occupying by the Cayo formation, which would serve as a basement and is forming by sandstones, volcanic greywackes with clayey matrix, which have very low permeability and good porosity.

These field-collected data correlate with resistivity data from the strata already established at this site (Table 1).

VES 2, 4, 7, 9, 11, 12, 13, 15, 16 and 17 have a greater possibility of locating groundwater due to their high resistivity values and the thickness of their layer of gravel and sand, which is greater than 8 meters, guaranteeing the existence of more significant water accumulation in that sector. Regarding the profiles carried out, we have: Profile A-A' (VES-03 and VES-04), Profile B-B' (VES-02 and VES-08) and Profile C-C'
(VES-05 and VES-07), these profiles are located along the Valdivia riverbed and are characterising by containing gravel and sand strata (these materials act as aquifer layers due to their high permeability). These strata are observing in Figure 5 .

Table 1. Range of resistivity values according to lithology

\begin{tabular}{cc}
\hline Resistivity & Lithology \\
\hline $\mathbf{0 - 1 5}$ & Clays with calcareous material \\
$\mathbf{1 5 - 2 5}$ & Sands \\
$\mathbf{2 5 - 4 0}$ & Clayey sand \\
$\mathbf{4 0 - 9 5}$ & Gravels with sand \\
$\mathbf{9 5 - 8 0 0 0}$ & Basement \\
\hline
\end{tabular}
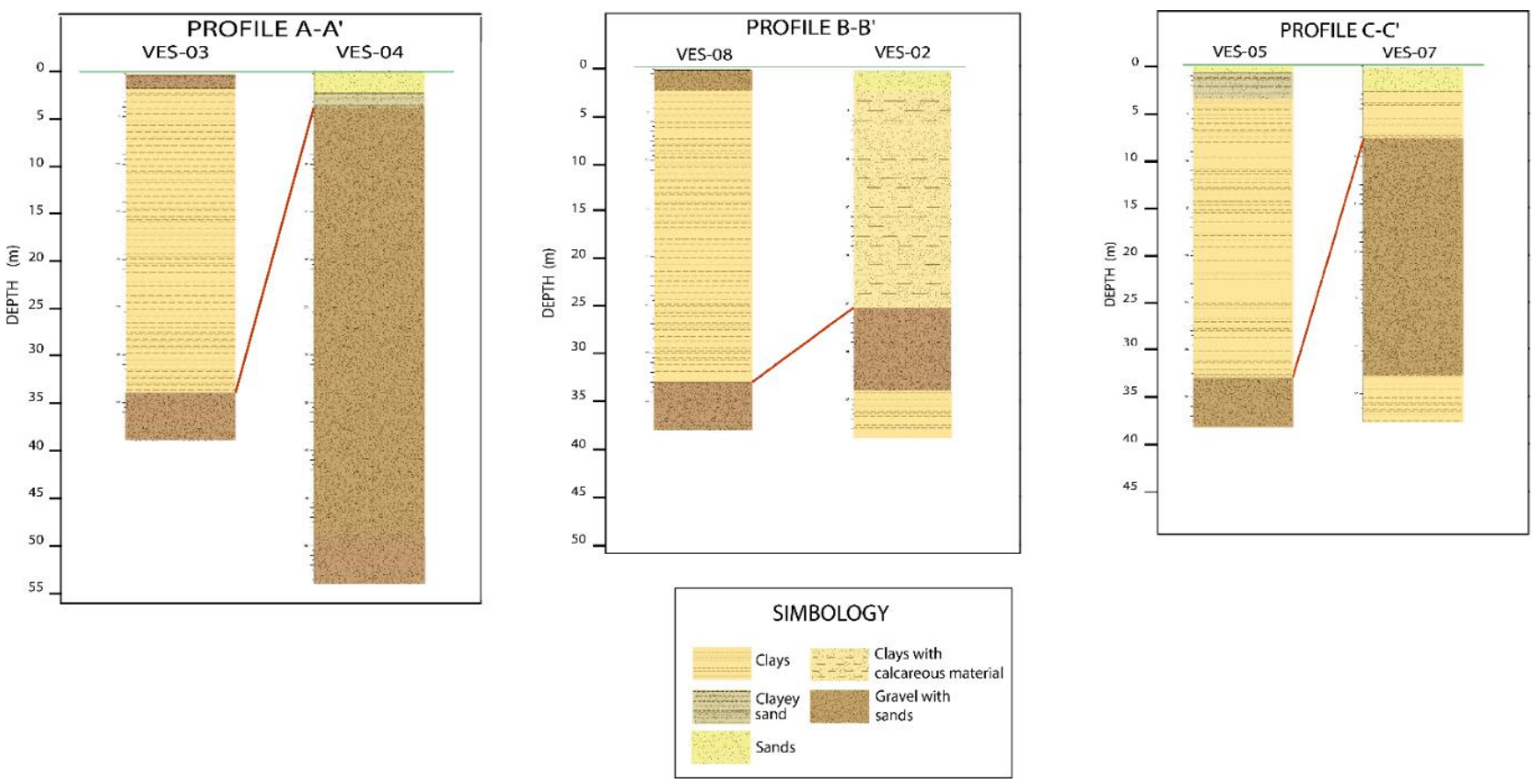

Figure 5. VES correlation of the taken in the field. (Profiles A-A', B-B' and C-C', see Figure 4)

\subsection{Physical-chemical analysis of water samples}

The physical-chemical parameters of the wells located in the Valdivia river basin are recorded in the field and analysed or compared with the optimum levels for water consumption established by the WHO (World Health Organization) [38] and by the TULSMA (Unified Text of Secondary Environmental Legislation) Book VI Annex 1 [39] (Table 2).

Most of the wells have a neutral $\mathrm{pH}(70 \%$, see Table 3$)$; however, in the wells for agricultural use (wells 2 and 11), their conditions are optimal because they maintain low salinity levels. On the other hand, wells 3 and 4 are not optimal even though they retain low salinity levels these contaminate larvae. The remaining wells have high salinity percentages; therefore, this water is considered salty, and its use is not recommending. On the other hand, in the JAAPR-Valdivia wells, all of them have salinity values higher than 0.5 . Therefore, their water is considered salty, so its use for human consumption is not recommending.

\subsection{SWOT analysis}

Figure 6 shows the summary of the SWOT analysis obtained from the workshop held with the commune representatives. The SWOT analysis identified four main problems: a) expired water and sanitation service tariffs, b) poor integrated management of water resources and overexploitation of the coastal aquifer, c) effects on agricultural productivity due to droughts (La Niña phenomenon), d) lack of support from national agencies.

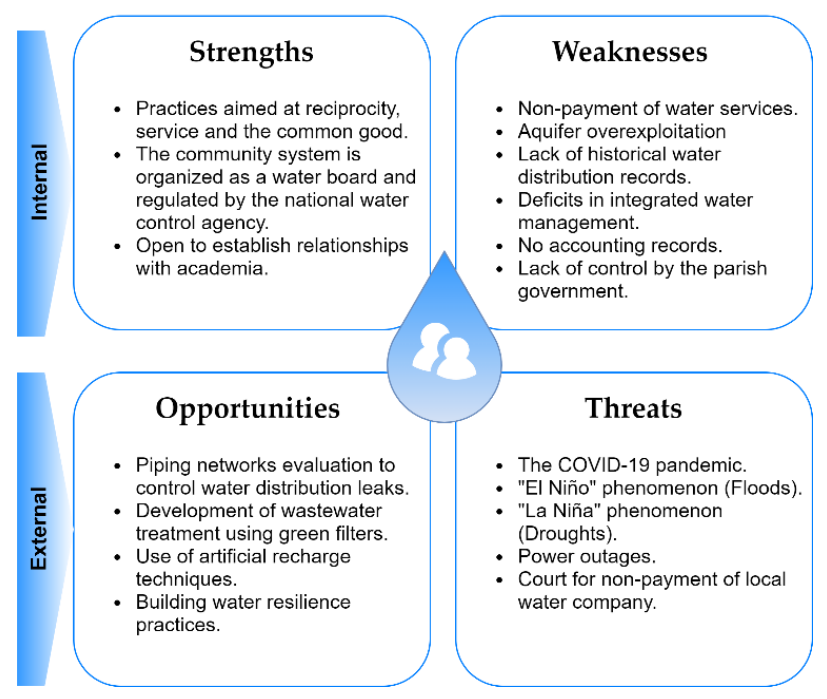

Figure 6. SWOT analysis 
Table 2. Reference ranges for the evaluation of water quality $[38,39]$

\begin{tabular}{cc}
\hline Parameters & Reference values \\
\hline pH & $6.5-9.5$ \\
Temperature $\left({ }^{\circ} \mathbf{C}\right)$ & $27-28$ \\
TDS $(\mathbf{g} / \mathbf{L})$ & $<1.2$ \\
Salinity $(\%)$ & $<=0.5$ \\
\hline
\end{tabular}

\subsection{Conceptual model of system river-aquifer}

As a result of the qualitative methodologies and hydrogeological studies, the variables that make up the riveraquifer system's socio-hydrogeological model are identifying. The model comprises four systems: hydrogeological, ecological, economic, and social, as shown in Figure 7. The socio-hydrogeological model and its elements are essential to establish improvements in the sustainable water management of JAAPR-Valdivia. The strategies are focused on developing sustainable agriculture practices, defining water recharge zones, building a habit of monthly monitoring of water quality and quantity of the coastal aquifer, implementing artificial recharge methods (e.g., construction of dams or "tapes"), developing reforestation campaigns in areas close to the aquifer, and training the water board and the community on the sustainable use and management of water resources.

By correlating the columns obtained from the VES interpretation (Figure 5), it is determining that the aquifer water flows through Quaternary alluvial deposits, with a lithological capacity ranging from 2 to 45 meters in most of the middle basin. Its lithology is composed mainly of sands, clays and gravels, with strengths ranging from a few meters to approximately 30 meters. In addition, it presents strata with a high content of calcareous material, indicating that the geological formations exposing to a marine environment.

Recharge of both the aquifer and the river depends on rainfall in the area. In the case of the aquifer, recharge takes place through the infiltration of precipitation in the strata that make up the alluvial terraces present in the basin. Another form of aquifer recharge occurs through the infiltration of water in the riverbed, which is the effect of runoff that originates in times of heavy rainfall and by the lighter rain known as "garúas" [40-42].

The discharge or outflow of water from the river and the aquifer are mainly due to the extractions made by the drinking water management boards (JAAPR-Valdivia, JAAP-"Loma Alta", JAAP-"La Unión", JAAP-"El Suspiro"), to supply their inhabitants. Other factors also influence river and aquifer discharge, such as Potential Evapotranspiration (ETP), which is the water that evaporates due to climatic factors, increasing the water deficit. Finally, there is the natural discharge of the Valdivia River to the sea.

Currently, the basin is affected by the "La Niña" phenomenon [43], which has caused the riverbed to drop until it is scorched so that populations are supplied only by the aquifer. When analysing the data on the physical-chemical parameters of the water from the wells near the sea, it is founding that most of them have a high saline content, which shows that the aquifer is affected by the saline intrusion, impairing the quality of the water extracted (Figure 8).

Table 3. Data records from wells located within the Valdivia River basin

\begin{tabular}{|c|c|c|c|c|c|c|c|c|c|c|c|c|}
\hline$\frac{\infty}{\overline{0}}$ & 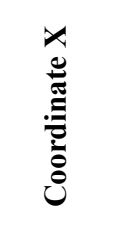 & ن & 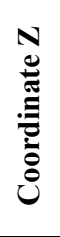 & $\begin{array}{l}\widehat{\Xi} \\
\bar{\Xi} \\
\overline{0} \\
\overline{0} \\
\overline{0} \\
\bar{z}\end{array}$ & 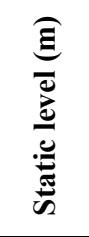 & $\overline{2}$ & 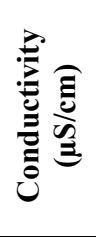 & 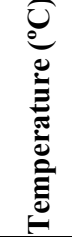 & 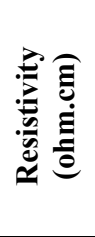 & 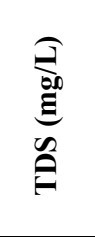 & 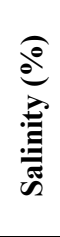 & 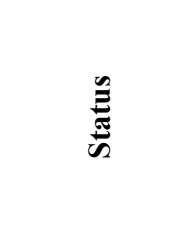 \\
\hline 1 & 534855 & 9786358 & 24 & - & - & - & - & - & - & - & - & Inactive \\
\hline 2 & 535107 & 9786355 & 23 & 13 & 9.9 & 7 & 1.034 & 27.7 & 967 & 1.034 & 0.5 & Active \\
\hline 3 & 535209 & 9786649 & 23 & 7.9 & 4 & 7 & 1.002 & 26.5 & 998 & 1.002 & 0.4 & Contaminated \\
\hline 4 & 535101 & 9786740 & 29 & 15.43 & 13.05 & 7 & 1.194 & 26.4 & 837 & 1.195 & 0.5 & Contaminated \\
\hline 5 & 534356 & 9785988 & 25 & 19.3 & 11,1 & 7 & 2.65 & 27.2 & 377 & 2.65 & 1.4 & Active \\
\hline 6 & 534244 & 9785957 & 29 & 19 & 11.5 & 7 & 3.14 & 27.6 & 318 & 3.15 & 1.6 & Active \\
\hline 7 & 533008 & 9786042 & 20 & 7.4 & 4.1 & 7 & 5.29 & 27 & 188.5 & 5.31 & 2.9 & Active \\
\hline 8 & 532824 & 9786069 & 20 & 4 & 3 & 7 & 3.83 & 26.1 & 260 & 3.84 & 2 & Active \\
\hline 9 & 532861 & 9786105 & 21 & - & - & - & - & - & - & - & - & Active \\
\hline 10 & 532972 & 9786029 & 26 & - & - & - & - & - & - & - & - & Active \\
\hline 11 & 534234 & 9786399 & 17 & 6.7 & 555 & 7 & 1.841 & 26.8 & 543 & 1.844 & 0.9 & Active \\
\hline 12 & 538285 & 9789151 & 47 & 6.2 & 3.8 & 7 & 12.83 & 26.9 & 77.9 & 12.83 & 7.4 & Active \\
\hline 13 & 538274 & 9789157 & 46 & 4 & 3 & 7 & 11.46 & 31.2 & 87.2 & 11.46 & 6.6 & Active \\
\hline 14 & 538300 & 9789157 & 47 & 5.65 & 3.7 & 7 & 4.44 & 27.5 & 225 & 4.44 & 2.4 & Active \\
\hline 15 & 534956 & 9786407 & 26 & - & - & 7 & 1.108 & 30 & 903 & 1.109 & 0.5 & Inactive \\
\hline 16 & 535332 & 9786504 & 21 & 12 & 4.8 & 7.05 & 2.11 & 35.5 & 473 & 2.11 & 1.1 & Active \\
\hline \multicolumn{13}{|c|}{ JAAPR-VALDIVIA WELLS } \\
\hline 1 & 536901 & 9788597 & 37 & - & - & 7 & 1671 & 28.7 & 599 & 1669 & 0.8 & Active \\
\hline 2 & 536691 & 9788187 & 32 & - & - & 7 & 1548 & 27.5 & 645 & 1552 & 0.7 & Active \\
\hline 4 & 534379 & 9785960 & 20 & - & - & - & - & - & - & - & - & Inactive \\
\hline 5 & 534363 & 9785950 & 20 & 18 & - & - & - & - & - & - & - & Inactive \\
\hline 6 & 534368 & 9785960 & 17 & 18 & - & 7 & 1839 & 29.3 & 543 & 1840 & 0.9 & Active \\
\hline 7 & 536939 & 9788565 & 37 & 13 & 3 & 7 & 1223 & 27.7 & 817 & 1224 & 0.6 & Inactive \\
\hline 8 & 536668 & 9787984 & 31 & 17 & - & - & - & - & - & - & - & Inactive \\
\hline
\end{tabular}




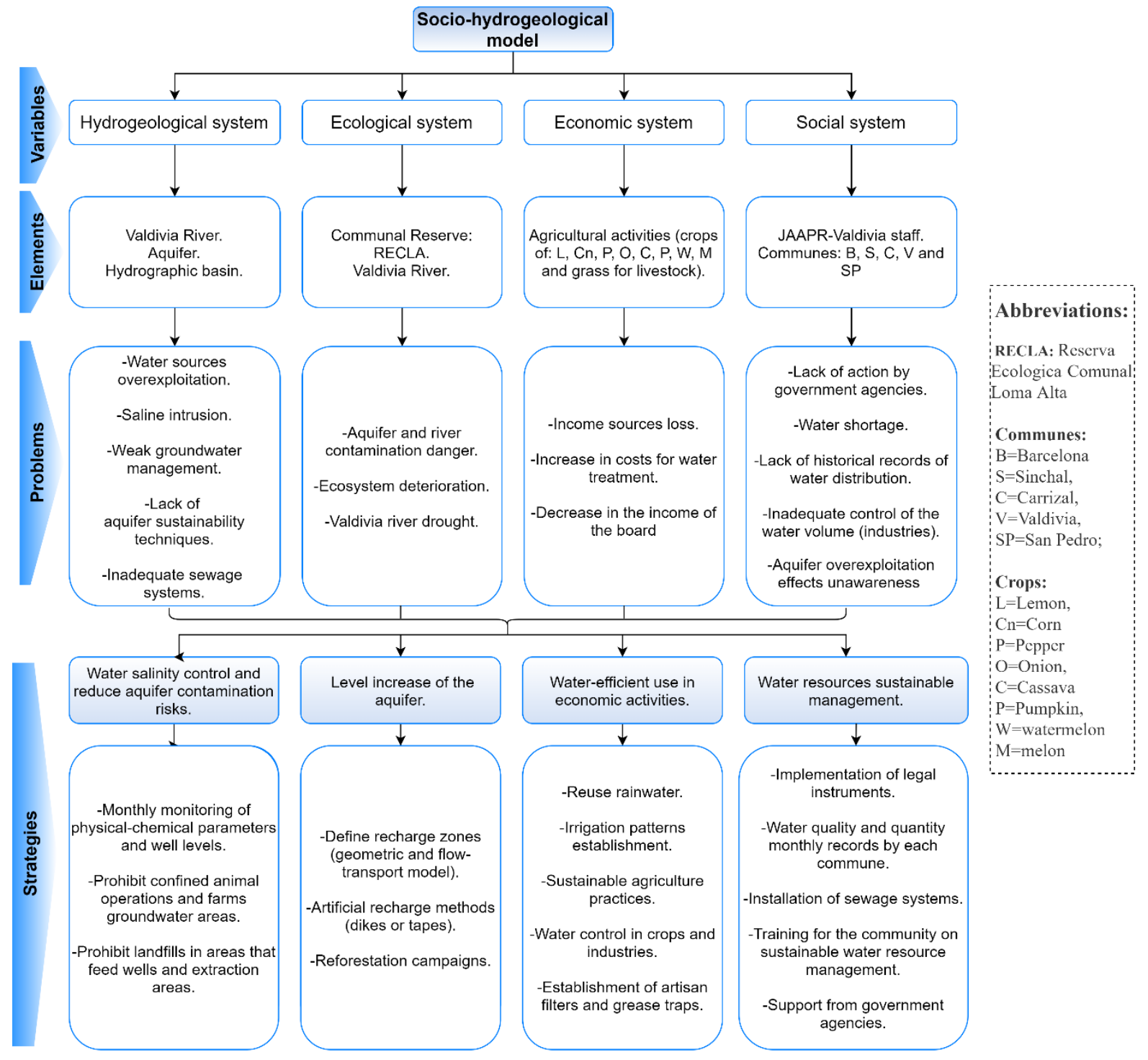

Figure 7. Proposal for a socio-hydrogeological model applied to sustainable water management in the Valdivia river basin (Santa Elena-Ecuador)

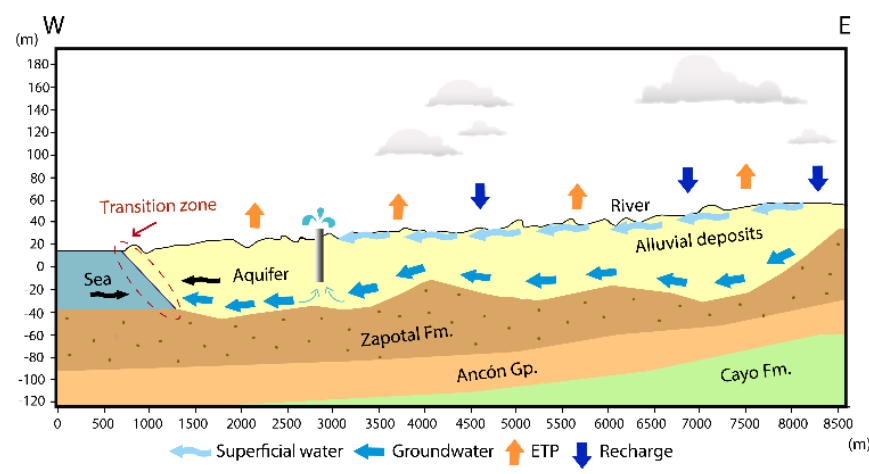

Figure 8. Conceptual model of the river-aquifer system of the Valdivia river basin

\section{RESULTS INTERPRETATION AND DISCUSSION}

The use of VES has proven to be effective in understanding the internal structure of aquifers [44, 45], as is the case in geoelectric measurements in the Yemen coastal plain [46]. The results obtained in the $17 \mathrm{SEVs}$ in the Valdivia river basin verify that more than $50 \%$ of the geologic layers have favourable groundwater storage material.

The use or implementation of additional techniques such as well drilling and hydrogeochemical analysis allows a better evaluation of the aquifer [47]. In addition, the participatory methodologies to assist water planning and management [4852].

Agriculture is an activity that in many cases is the basis of the rural economies [53, 54]. Despite efforts to develop water resilience capacities [55], farmers continue exposed to an unpredictable water supply [49].

The hydrological model of Bierkens and Wada [56] reveals that the expansion of irrigated agriculture in drylands has caused a global depletion of groundwater (of approximately 100 and $300 \mathrm{~km}^{3} \mathrm{yr}-1$ ). Activity threatens the sustainability and harmony between groundwater resources, economic development, and soil and water conservation [57].

In the case of coastal aquifers, their uncontrolled extraction generates effects such as contamination by salinisation processes $[58,59]$ and land subsidence due to fluctuations in the phreatic level $[60,61]$. In addition, soil chemicals are transported to the aquifer [62-64] and anthropogenic activities that affect its stability [65], such as industrial, agricultural and 
tourism development $[66,67]$.

The volume exploited in the Valdivia river basin, and the water quality in wells in the agricultural and industrial sectors are unknown. The hydrogeological studies absence represents a problem for the hydrographic basin. This basin needs to control the aquifer's exploited water to carry out the water balance-allowing to control that the extracted volume does not exceed the aquifer's recharge capacity.

Improving this problem would enable valuable data management and storage for the geometric modelling of the coastal aquifer applied in other studies [68, 69]. These data allow estimating the distribution of hydraulic conductivity, controlling the invasion of saline intrusion that affects these systems and establishing strategies to conserve them.

Hydrogeologists-community interaction turns out to play a vital role in the better management of groundwater resources [70]. The example presented in this research shows how using tools such as the qualitative methodologies PAR [34-36] allows working in close collaboration with community (Valdivia) from the definition of the problem, analysis of stakeholders and generate strategies to maintain and recharge groundwater resources. Especially in these semi-arid coastal areas [21], which experience significant challenges of access to freshwater [3, 4].

The coastal aquifer of the study constitutes an important source of irrigation water for the commune. However, being a system connected with the sea (Figure 8), overexploitation leads to the phenomenon of saline intrusion. As a result, half of the wells have a high level of salinity (Table 3 ).

Some river basins employ the so-called socio-hydrogeology model in the Grombalia basin in Tunisia (North Africa). Their approach called "Bir Al-Nas" [14] integrates hydrogeochemical studies with socio-economic [16] for groundwater management. However, research undoubtedly highlights that the basis for hydrogeological studies is communication [70]. Therefore, hydrogeology experts must succeed in imparting basic knowledge of hydrogeology, especially to rural communities. To ensure the sustainable development of groundwater resources [70].

The four systems of the socio-hydrogeology model of the Valdivia river basin (Figure 7) propose evaluating the hydrogeological aspect and other axes such as the ecological, economic and social. Including transversally the social dimension applied at the scale of a small river basin (southwestern Ecuador). Socio-hydrogeology is a recent discipline that proposes a new approach to groundwater studies in a geological era of the Anthropocene, where man is responsible for the pressure exerted on freshwater.

\section{CONCLUSIONS}

The Valdivia river basin's socio-hydrogeological approach to sustainable water management combines hydrogeological, ecological, economic and social analysis. The PAR method obtained a primary evaluation of the watershed environment, its elements, and interactions. The study shows the community organisation members' central role in managing the available groundwater resource. The result of qualitative methodologies highlighted the deficiencies in basic hydrogeological studies in the Valdivia commune. Therefore, it is necessary to generate more spaces for the interaction of hydrogeologistscommunity to develop the best water practices.

This research has incorporated the theoretical concept of socio-hydrogeology, in the case of the middle and lower basin of a river, where on the one hand, there is the technical and hydrogeological part related to the underground resource and, on the other hand, the social and cultural contributions taking into account ancestral knowledge, provided by the application of participatory methodologies (PAR). As a result, the treated case study can be used by decision-makers since it allows a conjunctive synergy for a comprehensive initial diagnosis, and in this way, offers solutions to the identified problems that adapt to the criteria and needs of the community.

The proposal of the socio-hydrogeological model allowed the detection of six problems: a) droughts due to the influence of natural phenomena ("La Niña" phenomenon), b) overexploitation of the aquifer, c) lack of aquifer sustainability techniques, d) weak management and control of water resources, e) contamination of water sources, and f) lack of support from government agencies.

In addition, the research generates proposals for strategies for the sustainable management of the aquifer. Such as sustainable agriculture practices (e.g., establish adequate irrigation patterns), define water recharge zones (e.g., development of the geometric model and flow and transport of the aquifer). Furthermore, build a habit of monthly monitoring of water quality and quantity of the coastal aquifer (e.g., participatory methods, workshops, PAR methodology), implementation of artificial recharge methods (e.g., construction of dikes or "tapes"), development of reforestation campaigns in areas near the aquifer, and training for the water board and the community on the sustainable use and management of water resources. Thus, the proposed sociohydrogeological model is an initial step in developing actions and strategies to seek sustainable solutions for the population it occupies.

\section{ACKNOWLEDGMENT}

This work is supported by the "Registry of geological and mining heritage and its impact on the defense and preservation of geodiversity in Ecuador" project by ESPOL University with code: CIPAT-01-2018. As well as the community service project entitled "Water Sowing and Harvesting in the face of COVID-19, Manglaralto 2021" with code: PG03-PY21-03. In addition, the authors thank the community organization "Junta Administradora de Agua Potable Regional de Valdivia (JAAPR-Valdivia)" for their cooperation in developing this research work.

\section{REFERENCES}

[1] Durack, P.J. (2015). Ocean salinity and the global water cycle. Oceanography, 28(1): 20-31. https://doi.org/10.5670/oceanog.2015.03

[2] Abbott, B.W., Bishop, K., Zarnetske, J.P., Minaudo, C., Chapin, F.S., Krause, S., Pinay, G. (2019). Human domination of the global water cycle absent from depictions and perceptions. Nature Geoscience, 12(7): 533-540. https://doi.org/10.1038/s41561-019-0374-y

[3] Mekonnen, M.M., Hoekstra, A.Y. (2016). Four billion people facing severe water scarcity. Science Advances, 2(2): e1500323. https://doi.org/10.1126/sciadv.1500323

[4] IPCC, 2021: Climate Change 2021: The Physical Science Basis. Contribution of Working Group I to the Sixth 
Assessment Report of the Intergovernmental Panel on Climate Change [Masson-Delmotte, V., P. Zhai, A. Pirani, S.L. Connors, C. Péan, S. Berger, N. Caud, Y. Chen, L. Goldfarb, M.I. Gomis, M. Huang, K. Leitzell, E. Lonnoy, J.B.R. Matthews, T.K. Maycock, T. Waterfield, O. Yelekçi, R. Yu, and B. Zhou (eds.)]. Cambridge University Press. In Press. https://www.ipcc.ch/report/ar6/wg1/\#FullReport.

[5] Hoff, H. (2011). Understanding the Nexus. Background paper for the Bonn2011 Nexus Conference: The Water, Energy and Food Security Nexus. https://www.sei.org/publications/understanding-thenexus/.

[6] Bizikova, L., Roy, D., Swanson, D., Venema, H.D., McCandless, M. (2013). The water-energy-food security nexus: Towards a practical planning and decisionsupport framework for landscape investment and risk management. Winnipeg: International Institute for Sustainable Development, 16-20. https://www.iisd.org/publications/water-energy-foodsecurity-nexus-towards-practical-planning-anddecision-support.

[7] D'Odorico, P., Davis, K.F., Rosa, L., Carr, J.A., Chiarelli, D., Dell'Angelo, J., Rulli, M.C. (2018). The global foodenergy-water nexus. Reviews of Geophysics, 56(3): 456531. https://doi.org/10.1029/2017RG000591

[8] Intergovernmental Panel on Climate Change. (2014). Freshwater Resources. In Climate Change 2014 Impacts, Adaptation and Vulnerability: Part A: Global and Sectoral Aspects: Working Group II Contribution to the IPCC Fifth Assessment Report (pp. 229-270). Cambridge: Cambridge University Press. https://doi.org/10.1017/CBO9781107415379.008

[9] Waters, C.N., Zalasiewicz, J., Summerhayes, C., Barnosky, A.D., Poirier, C., Gałuszka, A., Wolfe, A.P. (2016). The Anthropocene is functionally and stratigraphically distinct from the Holocene. Science, 351(6269). https://doi.org/10.1126/science.aad2622

[10] Ross, A., Chang, H. (2020). Socio-hydrology with hydrosocial theory: Two sides of the same coin? Hydrological Sciences Journal, 65(9): 1443-1457. https://doi.org/10.1080/02626667.2020.1761023

[11] Herrera-Franco, G., Montalván-Burbano, N., CarriónMero, P., Bravo-Montero, L. (2021). Worldwide research on socio-hydrology: A bibliometric analysis. Water, 13(9): 1283. https://doi.org/10.3390/w13091283

[12] Sivapalan, M., Savenije, H.H., Blöschl, G. (2012). Sociohydrology: A new science of people and water. Hydrol. Process, 26(8):

1270-1276. https://doi.org/10.1002/hyp.8426

[13] Sivapalan, M., Konar, M., Srinivasan, V., Chhatre, A., Wutich, A., Scott, C.A., Rodríguez-Iturbe, I. (2014). Socio-hydrology: Use-inspired water sustainability science for the Anthropocene. Earth's Future, 2(4): 225230. https://doi.org/10.1002/2013EF000164

[14] Re, V. (2015). Incorporating the social dimension into hydrogeochemical investigations for rural development: The Bir Al-Nas approach for socio-hydrogeology. Hydrogeology Journal, 23(7): 1293-1304. https://doi.org/10.1007/s10040-015-1284-8

[15] Re, V. (2021). Socio-hydrogeology and Geoethics-State of the Art and Future Challenges. In Advances in Geoethics and Groundwater Management: Theory and Practice for a Sustainable Development, 373-376. https://doi.org/10.1007/978-3-030-59320-9_77

[16] Tringali, C., Re, V., Siciliano, G., Chkir, N., Tuci, C., Zouari, K. (2017). Insights and participatory actions driven by a socio-hydrogeological approach for groundwater management: The Grombalia Basin case study (Tunisia). Hydrogeology Journal, 25(5): 12411255. https://doi.org/10.1007/s10040-017-1542-z

[17] Capítulo, L.R., Carretero, S.C., Kruse, E.E. (2017). Comparative study of urban development and groundwater condition in coastal areas of Buenos Aires, Argentina. Hydrogeology Journal, 25(5): 1407-1422. https://doi.org/10.1007/s10040-017-1544-X

[18] Re, V., Sacchi, E. (2017). Tackling the salinity-pollution nexus in coastal aquifers from arid regions using nitrate and boron isotopes. Environmental Science and Pollution Research, 24(15): 13247-13261. https://doi.org/10.1007/s11356-017-8384-Z

[19] Musacchio, A., Viviana, R., Delconte, C.A., Racchetti, E., Soana, E., Balestrini, R., Sacchi, E. (2019). Squaring the cycle: the integration of groundwater processes in nutrient budgets for a basin-oriented remediation Strategy. Rend. Online della Soc. Geol. Ital., 47: 73-78. https://doi.org/10.3301/ROL.2019.14

[20] Re, V., Thin, M.M., Tringali, C., Mya, M., Destefanis, E., Sacchi, E. (2021). Laying the groundwork for raising awareness on water related issues with a sociohydrogeological approach: The Inle Lake case study (Southern Shan State, Myanmar). Water, 13(17): 2434. https://doi.org/10.3390/w13172434

[21] García-Garizábal, I. (2017). Rainfall variability and trend analysis in coastal arid Ecuador. International Journal of Climatology, $\quad 37(13)$ : $\quad$ 4620-4630. https://doi.org/10.1002/joc.5110

[22] Borja, N., Cho, J., Choi, K. S. (2017). The influence of climate change on irrigation water requirements for corn in the coastal region of Ecuador. Paddy and Water Environment, 15(1): 71-78. https://doi.org/10.1007/s10333-016-0529-z

[23] Carrión-Mero, P., Morante-Carballo, F., Herrera-Franco, G., Jaya-Montalvo, M., Rodríguez, D., Loor-Flores de Valgas, C., Berrezueta, E. (2021). Community-university partnership in water education and linkage process. Study case: Manglaralto, Santa Elena, Ecuador. Water, 13(15): 1998. https://doi.org/10.3390/w13151998

[24] ASF. Alaska Satellite Facility. EARTHDATA, 2021. https://search.asf.alaska.edu/\#/?zoom=7.422\&center=80.782,-3.616\&polygon=POLYGON((-80.8103 -2.009,$80.5436-2.009,-80.5436-1.7869,-80.8103 \quad-1.7869$,$80.8103 \quad-2.009)) \&$ searchType=Geographic Search\&resultsLoaded=true \&granule=ALPSRP078637 150-RTC_HI_RES\&datas, accessed on Sep 8, 2021.

[25] Sistema Nacional de Información, 2014. https://sni.gob.ec/coberturas, accessed on Aug. 29, 2021.

[26] INAMHI. Red de estaciones meteorológicas e hidrológicas, https://inamhi.wixsite.com/inamhi/novedades.

[27] Oseji, J.O., Asokhia, M.B., Okolie, E.C. (2006). Determination of groundwater potential in obiaruku and environs using surface geoelectric sounding. Environmentalist, $26(4)$ : 301-308. https://doi.org/10.1007/s10669-006-0159-x

[28] Sikandar, P., Bakhsh, A., Arshad, M., Rana, T. (2010). The use of vertical electrical sounding resistivity method for the location of low salinity groundwater for irrigation 
in Chaj and Rachna Doabs. Environmental Earth Sciences, 60(5): 1113-1129. https://doi.org/10.1007/s12665-009-0255-6

[29] Gaikwad, S., Pawar, N.J., Bedse, P., Wagh, V., Kadam, A. (2021). Delineation of groundwater potential zones using vertical electrical sounding (VES) in a complex bedrock geological setting of the West Coast of India. Modeling Earth Systems and Environment, 1-15. https://doi.org/ 10.1007/s40808-021-01223-3

[30] Manu, E., Agyekum, W.A., Duah, A.A., Tagoe, R., Preko, K. (2019). Application of vertical electrical sounding for groundwater exploration of Cape coast municipality in the central region of Ghana. Arabian Journal of Geosciences, 12(6): 1-11. https://doi.org/10.1007/s12517-019-4374-4

[31] Arowoogun, K.I., Osinowo, O.O. (2021). 3D resistivity model of 1D vertical electrical sounding (VES) data for groundwater potential and aquifer protective capacity assessment: A case study. Modeling Earth Systems and Environment, 1-12. https://doi.org/10.1007/s40808-02101254-w

[32] Soomro, A., Qureshi, A.L., Jamali, M.A., Ashraf, A. (2019). Groundwater investigation through vertical electrical sounding at hilly area from Nooriabad toward Karachi. Acta Geophysica, 67(1): 247-261. https://doi.org/10.1007/s11600-019-00247-9

[33] Bobachev, C. (2002). IPI2Win: A windows software for an automatic interpretation of resistivity sounding data. Moscow State University, 320 https://www.scirp.org/(S(i43dyn45teexjx455qlt3d2q))/r eference/ReferencesPapers.aspx?ReferenceID=647007.

[34] Kelly, P.J. (2005). Practical suggestions for community interventions using participatory action research. Public Health Nursing, 22(1): 65-73. https://doi.org/10.1111/j.0737-1209.2005.22110.x

[35] Steiner, G., Posch, A. (2006). Higher education for sustainability by means of transdisciplinary case studies: An innovative approach for solving complex, real-world problems. Journal of Cleaner Production, 14(9-11): 877890. https://doi.org/10.1016/j.jclepro.2005.11.054

[36] Gricelda, H.F., Paúl, C.M., Niurka, A.M. (2018). Participatory process for local development: Sustainability of water resources in rural communities: Case manglaralto-santa elena, ecuador. In Handbook of Sustainability Science and Research, 663-676. https://doi.org/10.1007/978-3-319-63007-6_41

[37] Dyson, R.G. (2004). Strategic development and SWOT analysis at the University of Warwick. European Journal of Operational Research, 152(3): 631-640. https://doi.org/10.1016/S0377-2217(03)00062-6

[38] OMS, Guías para la calidad del agua potable, Tercera Ed. 2013.

https://www.who.int/water_sanitation_health/dwq/gdwq 3_es_fulll_lowsres.pdf.

[39] MAE, Norma de la calidad de agua ambiental y de descarga de efluentes. Quito, Ecuador: TULSMA, 2017, p. Libro VI, Anexo 1. https://www.ambiente.gob.ec/wpcontent/uploads/downloads/2018/05/Acuerdo-097.pdf.

[40] Freile, J.F. (2005). Áreas importantes para la conservación de las aves en Ecuador. Aves y Conservación.

[41] Sheppard, G. (1930). Notes on the climate and physiography of southwestern Ecuador. Geographical Review, 20(3): 445-453. https://doi.org/10.2307/209103
[42] Sonnenholzner, J., Brandt, M., Francisco, V., Hearn, A., Luzuriaga, M., Guarderas, P., Navarro, J.C. (2013). Echinoderms of ecuador. In Echinoderm research and diversity in Latin America, 183-233. https://doi.org/10.1007/978-3-642-20051-9_6

[43] El Fenómeno de La Niña está en su fase final. http://www.espol.edu.ec/es/noticias/el-fenómeno-de-laniña-está-en-su-fase-final, accessed on May 2, 2021

[44] Khalil, I. (2015). Geo-electrical soundings and analysis to investigate groundwater aquifers at Khulna City, coastal area of Bangladesh. Arabian Journal of Geosciences, $8(8)$ : 5325-5334. https://doi.org/10.1007/s12517-014-1636-z

[45] Gopinath, S., Srinivasamoorthy, K., Saravanan, K., Suma, C.S., Prakash, R., Senthinathan, D., Sarma, V.S. (2018). Vertical electrical sounding for mapping saline water intrusion in coastal aquifers of Nagapattinam and Karaikal, South India. Sustainable Water Resources Management, 4(4): 833-841. https://doi.org/10.1007/s40899-017-0178-4

[46] Van Overmeeren, R.A. (1989). Aquifer boundaries explored by geoelectrical measurements in the coastal plain of Yemen: A case of equivalence. Geophysics, 54(1): 38-48. https://doi.org/10.1190/1.1442575

[47] Hwang, S., Shin, J., Park, I., Lee, S. (2004). Assessment of seawater intrusion using geophysical well logging and electrical soundings in a coastal aquifer, Youngkwanggun, Korea. Exploration Geophysics, 35(1): 99-104. https://doi.org/10.1071/EG04099

[48] Herrera-Franco, G., Alvarado-Macancela, N., GavínQuinchuela, T., Carrión-Mero, P. (2018). Participatory socio-ecological system: Manglaralto-santa elena, Ecuador. Geology, Ecology, and Landscapes, 2(4): $303-$ 310. https://doi.org/10.1080/24749508.2018.1481632

[49] Singh, C. (2018). Is participatory watershed development building local adaptive capacity? Findings from a case study in Rajasthan, India. Environmental Development, 25: 43-58. https://doi.org/10.1016/j.envdev.2017.11.004

[50] Barthel, R., Foster, S., Villholth, K.G. (2017). Interdisciplinary and participatory approaches: the key to effective groundwater management. Hydrogeology Journal, 25(7): 1923-1926. https://doi.org/10.1007/s10040-017-1616-y

[51] Gricelda, H.F., Paúl, C.M., Niurka, A.M. (2018). Participatory process for local development: Sustainability of water resources in rural communities: Case manglaralto-santa elena, ecuador. In Handbook of Sustainability Science and Research, 663-676. https://doi.org/10.1007/978-3-319-63007-6_41

[52] Cradock-Henry, N.A., Blackett, P., Hall, M., Johnstone, P., Teixeira, E., Wreford, A. (2020). Climate adaptation pathways for agriculture: insights from a participatory process. Environmental Science \& Policy, 107: 66-79. https://doi.org/10.1016/j.envsci.2020.02.020

[53] Hammond, B., Berardi, G., Green, R. (2013). Resilience in Agriculture: Small-and medium-sized farms in Northwest Washington State. Agroecology and Sustainable Food Systems, 37(3): 316-339. https://doi.org/10.1080/10440046.2012.746251

[54] Buikstra, E., Ross, H., King, C.A., Baker, P.G., Hegney, D., McLachlan, K., Rogers-Clark, C. (2010). The components of resilience-Perceptions of an Australian rural community. Journal of Community Psychology, 38(8): 975-991. https://doi.org/10.1002/jcop.20409 
[55] Freeman, S.S.G., Brown, C., Cañada, H., Martinez, V., Nava, A.P., Ray, P., Boltz, F. (2020). Resilience by design in Mexico City: A participatory humanhydrologic systems approach. Water Security, 9: 100053. https://doi.org/10.1016/j.wasec.2019.100053

[56] Bierkens, M.F., Wada, Y. (2019). Non-renewable groundwater use and groundwater depletion: A review. Environmental Research Letters, 14(6): 063002. https://doi.org/10.1088/1748-9326/ab1a5f

[57] Lin, Y., Li, Q., Ji, K., Li, X., Yu, Y., Zhang, H., Sun, L. (2014). Thermogravimetric analysis of pyrolysis kinetics of Shenmu bituminous coal. Reaction Kinetics, Mechanisms and Catalysis, 113(1): 269-279. https://doi.org/10.1007/s11144-014-0731-1

[58] Gimenez, E., Morell, I. (1997). Hydrogeochemical analysis of salinization processes in the coastal aquifer of Oropesa (Castellon, Spain). Environmental Geology, 29(1-2): 118-131. https://doi.org/10.1007/s002540050110

[59] Carrión-Mero, P., Montalván, F.J., Morante-Carballo, F., Loor-Flores de Valgas, C., Apolo-Masache, B., Heredia, J. (2021). Flow and transport numerical model of a coastal aquifer based on the hydraulic importance of a dyke and its impact on water quality: ManglaraltoEcuador. Water, 13(4): 443. https://doi.org/10.3390/w13040443

[60] Antonellini, M., Giambastiani, B.M.S., Greggio, N., Bonzi, L., Calabrese, L., Luciani, P., Severi, P. (2019). Processes governing natural land subsidence in the shallow coastal aquifer of the Ravenna coast, Italy. Catena, 172:

76-86. https://doi.org/10.1016/j.catena.2018.08.019

[61] Yang, J., Cao, G., Han, D., Yuan, H., Hu, Y., Shi, P., Chen, Y. (2019). Deformation of the aquifer system under groundwater level fluctuations and its implication for land subsidence control in the Tianjin coastal region. Environmental Monitoring and Assessment, 191(3): 114. https://doi.org/10.1007/s10661-019-7296-4

[62] El Ayni, F., Cherif, S., Jrad, A., Trabelsi-Ayadi, M. (2012). Impact of agriculture activities on a coastal aquifer in Tunisia and options for a better water management. Water International, 37(7): 871-883. https://doi.org/10.1080/02508060.2012.733671

[63] Jayasingha, P., Pitawala, A., Dharmagunawardhane, H.A. (2011). Vulnerability of coastal aquifers due to nutrient pollution from agriculture: Kalpitiya, Sri Lanka. Water, Air, \& Soil Pollution, 219(1): 563-577. https://doi.org/10.1007/s11270-010-0728-y

[64] Carrión-Mero, P., Montalván, F.J., Morante-Carballo, F., Heredia, J., Elorza, F.J., Solórzano, J., Aguilera, H. (2021). Hydrochemical and isotopic characterization of the waters of the Manglaralto River Basin (Ecuador) to contribute to the management of the coastal aquifer. Water, 13(4): 537. https://doi.org/10.3390/w13040537

[65] Calvache, M.L., Pulido-Bosch, A. (1997). Effects of geology and human activity on the dynamics of saltwater intrusion in three coastal aquifers in southern Spain. Environmental Geology, 30(3-4): 215-223. https://doi.org/10.1007/s002540050149

[66] Li, Q., Zhang, Y., Chen, W., Yu, S. (2018). The integrated impacts of natural processes and human activities on groundwater salinization in the coastal aquifers of Beihai, southern China. Hydrogeology Journal, 26(5): 1513-1526. https://doi.org/10.1007/s10040-018-1756-8

[67] Rapti-Caputo, D. (2010). Influence of climatic changes and human activities on the salinization process of coastal aquifer systems. Italian Journal of Agronomy, 5(s3): 67-80. https://doi.org/10.4081/ija.2010.s3.67

[68] Boufekane, A., Saibi, H., Benlaoukli, B., Saighi, O. (2019). Scenario modeling of the groundwater in a coastal aquifer (Jijel plain area, Algeria). Arabian Journal of Geosciences, 12(24): 1-14. https://doi.org/10.1007/s12517-019-4965-0

[69] Carrión-Mero, P., Quiñonez-Barzola, X., MoranteCarballo, F., Montalván, F.J., Herrera-Franco, G., PlazaÚbeda, J. (2021). Geometric model of a coastal aquifer to promote the sustainable use of water. Manglaralto, $\begin{array}{lll}\text { Ecuador. } & \text { Water, } & \text { 13(7): }\end{array}$ https://doi.org/10.3390/w13070923

[70] Limaye, S.D. (2017). Socio-hydrogeology and lowincome countries: Taking science to rural society. Hydrogeology Journal, 25(7): 1927-1930. https://doi.org/10.1007/s10040-017-1656-3 